\title{
Practicing Teachers' Perceptions of Teacher Trainees: Implications for Teacher Education
}

\author{
Alice Merab Kagoda ${ }^{1}$, John Sentongo ${ }^{2}$ \\ ${ }^{1}$ Department of Humanities and Language Education, Makerere University, Uganda \\ ${ }^{2}$ Department of Science, Technical and Vocational Education, School of Education, Makerere University, Uganda
}

Copyright $(2015$ Horizon Research Publishing All rights reserved.

\begin{abstract}
Practicing teachers are partners in preparation of teacher trainees. However, little is known about their perceptions of the teacher trainees they receive every year in their schools. Ninety three practicing teachers from twenty schools participated in this study. The objectives were to find out the practicing teachers' perceptions of teacher trainees' behaviors and knowledge of subject content as well as teaching methods they use. Secondly, to find out how teacher trainees' relate to both teaching and non-teaching staff in the schools where they posted and to the students they teach. Thirdly, to assess teacher trainees' participation in extra-curricular activities and any other issues relating to their stay in the schools. Questionnaires and focus group discussions were used to collect data. Results show that practicing teachers perceive teacher trainees as follows; they are fairly good regarding professional ethics, they dress well except some girls who dress poorly, the majority of teacher trainees do not exhibit masterly of the subject matter in their respective subjects and most of them participate in school activities if assigned to do that. Researchers recommend that teacher trainees need more subject matter guidance from their subject lecturers and support from the subject teachers in schools where they do school practice. The idea of team work should be instilled in teacher trainees so that they support one another in schools where they practice from. The School of Education should intensify its relationship with practicing teachers in the process of preparing teachers. The course on professional ethics for teachers should be more practical so that the teacher trainees are properly guided before they graduate.
\end{abstract}

Keywords Practicing Teachers, Teacher Trainees, Teacher Education

\section{Introduction}

The main purpose for school practice is to provide opportunities to teacher trainees to put in practice pedagogical theories and skills while in schools. It is assumed that this knowledge and skills is situated in the day to day lived experiences of teachers and best understood through critical reflection with others who share the same experience,Vescio, Ross and Adams [1], Niemi and Jakku Sihvonen [2]. By actively engaging teacher trainees in school situations, they will increase their professional knowledge and enhance their learning. It is also hoped teacher trainees will also discover their own intellectual resources and to make them better able to work in changing contexts, Niemi and Jakku - Sihvonen [2]. The teacher trainees develop their own teaching skills, learn to plan, teach and evaluate teaching in terms of the curriculum, the school community and the age and learning capacity of students. Teacher trainees learn how to cooperate with other teachers, parents and other stakeholders of the society as a whole. Ideally these teacher trainees' learning is guided and supervised by University lecturers and local school teachers. The purpose of this study is to identify and explain contribution of /practicing teachers in the preparation of teacher trainees in training programme at the School of Education.

To become a professional teacher is a long learning process. Teacher development therefore implies guiding teachers develop the confidence to work with learners in real situations and teacher trainees need practical advice during their school practice. This experience in teaching is the integration of different kinds of knowledge (Davanport and Prusak 1998) quoted by Niemi and Jakku - Sihvonen [2]. Teacher professional training also needs role models, observing experts, tacit knowledge, a social network and even good stories of successful practice. They argue that this expert knowledge is deep personal knowledge which has been tested in practical situations. Expert knowledge, they add on is rational knowledge with principles, rules and models and teacher trainees need to know how to apply scientific theories and techniques to complex problems. Teacher training therefore is connected with more general social and political theories about such issues as democracy, social justice equality, legitimacy, gender, diversity in schools, sustainable development and inclusive education to mention a few. In Finland, teaching practice has a close 
relationship with learning "research", (Niemi and Jakku Sihvonen [2], behaviour research methods are obligatory for subject teachers. The ability to use research methods is considered crucial requiring studies of both qualitative and quantitative research traditions. The purpose is to train students to find and analyse problems they may expect to face in their future work. To the Australian, Carpenter and Blance [3] and internship in teacher education programme means ".....extended field based and context - responsive professional learning experiences negotiated collaboratively by stakeholders in the culminating phase of pre-service teacher preparation. The intern is mentored and immersed in a broad range of teacher's professional work activities. It involves a shift in status for the pre-service teacher with increased opportunities for autonomy, responsibility and accountability but with a safety net. The classroom teacher's relationship with the intern moves from evaluative to collegial", Board of Teacher Registration [4].

\section{Goals of Teaching Practice in Teacher Education}

According to Finish Teacher Education, Niemi and Jakku - Sihvonen [2]; Australian Teacher Education, Carpenter and Blance [3] and the Faculty of Education, University of Regina [5], teaching practice / internship generally has the following goals:

- The main objective of teaching practice is to support teacher trainees in their effort to acquire professional skills in researching, developing and evaluating teaching and learning processes.

- The teacher trainees will demonstrate their ability to use pedagogical skills in a variety of settings.

- Teacher trainees will demonstrate their ability to use that content they were exposed to in pedagogical settings and to identify and master new appropriate content.

- It is assumed classrooms will include students of diverse backgrounds and learning characteristics. Teacher trainee will be responsible for the learning of all students within the classroom and demonstrate growth in differentiating content, instructional strategies, resources and assessment procedures.

- Teacher trainees to experience challenges of teaching full-time including teacher's role in parent-teacher interviews, as a member of the staff and as a member of a wider community of human service professionals.

- Engage in critical reflective practice, continually evaluating the effects of their choices and actions on others and actively seek opportunities to challenge oppressive or inequitable situations or structures.

- Gain a deeper understanding of professionalism: the process of a unique body of knowledge and skills, membership in a professional organization, the adherence to a code of ethics, and the manifestation of an altruistic view toward students.
- Demonstrate ability to develop and maintain suitable relationships with students, teachers, the practicing teacher and administration, parents and peers. The teacher trainee will learn to place a high value on these relationships as a fundamental part of teaching.

- Contribute to the school and school community by participating in co-curricular activities, and community events, leading to attending workshops and showing interest and commitment to many other aspects of the school community.

\section{Values of Teaching Practice}

Carpenter and Blance [3] believe that teaching practice provides opportunity for developing a three way partnership between the university, the school and teacher trainees. This partnership is collaborative, neutrally advantageous and shares governance and evaluation of the programme.

Teacher trainees gain real world experience within a school culture where they can develop a range of personal and professional attributes. They develop awareness of a workplace culture and the fluidity of the rapidly changing world.

Practicing teachers have opportunity to develop professionally as they serve as mentors, teacher leaders and co-researchers to cohorts of teacher trainees. The practicing teachers benefit from an injection of new ideas that enhance their own professional growth and development through introduction of innovative ideas and current practices introduced by the teacher trainees. In addition, teaching practice is important in the following ways;

- Practicing teachers get time to initiate new projects that will be of benefit to the school community.

Schools become extended teacher education programme by participating in the training of teachers.

Schools have opportunity to having a pool of talented graduate teachers eligible for employment schools will make informed decisions regarding staffing needs

- Teaching practice has the potential to challenge the culture of isolation because it promotes the notion of a learning community. Teachers often become isolated because of lack of time and energy as a result of constant educational reforms. The teaching practice is challenged by increased collaboration in school university partnership and shared responsibility for the internship program, professional development for supervising teachers and a rich school experience for teacher trainees.

- The university's academic programme can be strengthened and academic reputation of the university increases

University's collaboration/cooperation with schools has the potential to develop the type of learning community that is required for schools to prepare students for a new socio-economic era marked by both rapid local and global change. 
Carpenter and Blance [3] add on that learning communities encourage life long learning and facilitate the adaptation to change which is a critical component for success.

\section{Context of the Study}

The School of Education is one of Makerere University largest schools with three departments highlighting Educational Foundations and Management which include; Curriculum teaching and Media, The department of Humanities and Languages Education and the department of Science, Technical and Vocational Education. The School of Education offers the professional teacher education courses while content for the disciplines except biology is offered in the faculties of Arts, Science and Faculty of Economics and Management. As a consequence of liberalization and privatization of education in Uganda, numbers of both day and evening students increased four times in the period 2000-2010. The number of teacher trainees increased from 500 in 1970's to 4500 by 2009 . Second and third year students and the teacher trainees pursuing a Post Graduate Diploma in Education are posted to secondary schools for school practice. The number of teacher trainees (T.Ts) on school practice ranges between 1700 and 2800 each year. The number of full and part-time lecturers in the School of Education is approximately one hundred (100). This number of lecturers is inadequate to supervise the teacher trainees. Consequently lecturers with a teaching certificate from other faculties at Makerere University, as well as from other universities like Kyambogo University as well as secondary school teachers with a Masters Degree in Education, are recruited to help supervise teacher trainees on school practice. To ease school practice management, School of Education divided Uganda into 21 zones each which is assigned to a zone leader. At the beginning of the academic year, School of Education sends out zone leaders to identify suitable schools for students' placement. Information about the identified schools in each zone is availed to students to choose which schools go to. For a school to be acceptable by the School of Education School Practice Committee, it has to be registered by the Ministry of Education and Sports.

\section{Statement of the Problem}

Training teachers is a partnership between teachers training colleges, the secondary schools and stakeholders in the education system. The School of Education sends out teacher trainees to schools every year on school practice but School of Education does not clearly state how the secondary schools are expected to contribute to the training of these teacher trainees. The other stakeholders like the Ministry of Education and sports don't seem to be involved in this important learning activity in the secondary schools which they directly control. School practice is a yearly routine prescribed by teacher training colleges which the researchers have reflected on to assess its effectiveness in preparing teacher trainees.

\section{Main Purpose of the Study}

To assess the perceptions and attitudes of practicing teachers and administrators toward the teacher trainees on school practice in their schools.

\section{Objectives of the Study}

The study addressed the following objectives:

1. Analyse the behaviour of teacher trainees in the areas of professional ethics, dressing code, and general discipline as observed by practicing teachers.

2. Assess the competences of teacher trainees in the subject content and their pedagogical skills.

3. Assess teachers trainees' participation in co-curricular activities including preparation of supervision of examinations where applicable.

4. Examine teacher trainees' relationship with the students and practicing teachers.

\section{Methodology}

This is a qualitative study backed up by simple quantitative statistics focusing on teacher's perceptions and attitudes. Five districts of Iganga, Mayuge, Luuka in Eastern and Kampala and Wakiso districts in Central Uganda participated in this study. Open ended questionnaires were used to get general overview of teacher's perceptions and attitudes. Focus group discussions were held with five focus groups of ten teachers. This method was used to clarify issues identified in responses by teachers to certain questions in the questionnaire.

The questionnaires were administered by two research assistants, one in eastern and another in Central Uganda. The two researchers, after analysing the questionnaires identified issues of discussion with teachers in the focus groups.

\section{Presentation of Data}

The main purpose of the study was to find out practicing teacher's perceptions of teacher trainees' knowledge and skills, practices and behaviour during school practice. Data is presented in Table 1 under sub topics of subject content and its delivery, professional ethics, relationships with practicing teachers and students plus their participation in extra curricular activities.

Table 1 below presents practicing teachers' views on teacher trainees'subject content and its delivery, professional 
ethics, relationships with practicing teachers, students, support staff and parents and their participation in extra-curricular activities.

Table 1. Practicing Teachers' views on Teacher Trainees' conduct during school practice

\begin{tabular}{|c|c|c|c|}
\hline Trainees' behavior & Description & $\begin{array}{l}\text { Frequency } \\
\text { (f) }\end{array}$ & $\begin{array}{l}\text { Percent } \\
\text { age }(\%)\end{array}$ \\
\hline \multirow{2}{*}{ Dress code } & Decent & 88 & 95 \\
\hline & - Indecent & 5 & 5 \\
\hline \multirow{2}{*}{ Discipline } & - Disciplined & 90 & 97 \\
\hline & Not disciplined & 3 & 3 \\
\hline \multicolumn{4}{|l|}{$\begin{array}{l}\text { Teacher trainees } \\
\text { relation with: }\end{array}$} \\
\hline \multirow{2}{*}{ Students } & Good & 89 & 96 \\
\hline & Poor & 4 & 4 \\
\hline \multirow{2}{*}{ Practicing teachers } & Good & 92 & 99 \\
\hline & Poor & 1 & 1 \\
\hline \multirow{2}{*}{ Subject content } & $\begin{array}{c}\text { Have adequate } \\
\text { content }\end{array}$ & 90 & 97 \\
\hline & $\begin{array}{c}\text { Have inadequate } \\
\text { content }\end{array}$ & 3 & 3 \\
\hline \multirow{2}{*}{ Content delivery } & Appropriate & 89 & 96 \\
\hline & Not appropriate & 4 & 4 \\
\hline \multicolumn{4}{|l|}{$\begin{array}{l}\text { Participation in school } \\
\text { activities }\end{array}$} \\
\hline \multirow{2}{*}{ Games } & Yes & 85 & 91 \\
\hline & No & 8 & 9 \\
\hline \multirow{2}{*}{ Assembly } & Yes & 78 & 84 \\
\hline & No & 15 & 16 \\
\hline Clubs & Yes & 87 & 94 \\
\hline
\end{tabular}

Practicing teacher's response to teacher trainees' knowledge of content and how it is delivered.

When Practicing teachers were asked to comment on teacher trainees subject content, $97 \%$ of the participants in the study believed the teacher trainees have adequate knowledge of the subject content "They handle content appropriately especially in their areas of specialization" others said, "although they have the content, they prepare little content and cover little in terms of topics in the syllabus". The practicing teachers do not mention much about the methods used by the teacher trainees however a few practicing teachers pointed out that "delivery of content is sometimes mainly based on what they can do instead of what can benefit learners". They argue that teacher trainees are more anxious about their supervisors' assessment of their teaching and this affects the way they teach. "They don't even cater for individual differences among the students in their class", one of the participants commented. The majority of the practicing teachers, 96\% believe teacher trainees use appropriate methods of teaching class discussion and demonstration. However, 4\%teachers reported that teacher trainees use teacher t-centred methods which are not relevant USE.
Teacher trainees' professional ethics in this study includes: the dressing code, discipline including their relationship with the students they teach. $96 \%$ of the practicing teachers said teacher trainees dress decently. Other teachers however, said teacher trainees do not mind how they dress. They commented that

Some female trainees wear tight short or long skirts with high healed shoes, while the male wear tight shirts and trousers referred to as "fitting" and some do not iron their clothes.

They went on to say that

Dress code is wanting, men put on T-shirts and tight trousers while ladies wear a lot of makeup and tight dresses (Focus group discussion with teachers)

Regarding the discipline of teacher trainees, $97 \%$ of the practicing teachers said the teacher trainees are disciplined and others added that they are punctual, cooperative and work in team when given tasks to do. Teacher trainees according to some practicing teacher, tend to strategically befriend their students so that when the supervisors appear in the class, she/he will get the impression that there is a good classroom control. Some however, said that a few male teacher trainees fall in love with their students and have sex with them. They add that some female teacher trainees tend to over associate with male practicing teachers.

Generally practicing teachers in the focus group discussions reported that "Teacher trainees behave professionally while on school practice. Their professional ethics are above average and acceptable". Teacher trainees' relationship with practicing teachers is variously described by the practicing teachers who participated in the study. $99 \%$ said the relationship between teacher trainees and practicing teachers is good, teacher trainees are friendly, cooperative and social, they are always friendly to the opposite sex; while others said teacher trainees tend to isolate themselves from practicing teachers and sit behind in the staffroom.

\section{Mentorship of teacher trainees by practising teachers}

The practicing teachers help teacher trainees to settle in the school in different ways. Some practicing teachers reported that they "discuss topics with them to help teacher trainees understand the subject matter and show them how to write notes for students". Some are given instructional materials, guide them how to writes schemes of work and lesson plans. On the other hand some practicing teachers reported that teacher trainees are mentored in the following manner: they guide them how to organize school assembly and encourage them to address assembly. They guide them how to handle large classes, advising them to dress appropriately; act as models for them and allow them to administer punishments to students. However, many practicing teacher just assign duties to trainees which include marking scripts, teaching which at times affects their participation in other activities. One practicing teacher pointed out 
I just give them a time-table, show them the class and introduce them to the students, show them the laboratory and give them text books to use. Finally avail them with the topics they are supposed to teach (Focus group discussion with teachers).

\section{Other teachers added that}

Mentorship is rarely done... teacher leave trainees on their own... this is the time to do" any other business (AOB).. some trainees are not available to be mentored, they are full time teachers in other schools (Focus group discussion)

Some practicing teachers went ahead to suggest how mentorship for teacher trainees can be promoted. Teacher trainees should be available at school and consult practicing teachers as much as possible; practicing teachers should sit in teacher trainees' lessons to identify areas where they need assistance and that practicing teachers should not leave teacher trainees on their own .Practicing teachers were asked what they felt they learn from teacher trainees. Practicing teachers get time for resting since teacher trainees take over their classes, they feel teacher trainees make good teaching aids like charts which they leave at school, get new teaching methods and skills, help to complete the syllabus very early, learn new things like making a record of work, teacher trainees help teachers on duty to run programmes like influencing learner's attitudes towards games and sports when they get involved, and they help in supervising examinations. "In fact they are very helpful during examinations since they are always present at school", one of the teachers commented.

The teacher trainees also benefit from practicing teachers as well. They gain experience in teaching, methods, skills and techniques of content delivery. They gain confidence; acquire skills of handling students in and out of class. They learn how to conduct themselves as teachers; they learn how to dress decently, how to identify learner behaviours, how to handle large classes, how to teach difficult topics. They also learn how to draw well designed scheme, acquire assessment skill and lastly one teacher said "teacher trainees are informed of the current syllabus which they do not get exposed to at the university".

The school administrators i.e. head teachers, deputy head teachers and director of studies were requested to give their opinion about teachers trainees. Administrators like practicing teachers gave divergent responses. According to the administrators, teacher trainees are generally well behaved and respect the people in the school community. They are very useful in the school because they play a big role in shaping the students' academics. They are always working to fulfil what is expected of them in all aspects. Some said, "teacher trainees have full mastery of the subject matter, they guide and counsel learners on several issues. On the other hand, some administrators pointed out that a few teacher trainees seem to be lacking some information about the professional code of dressing; some are not friendly and cooperative while others teach to pass not to make learners understand.

Consequently, the administrators recommended that the School of Education should:

- Incorporate Uganda National Examinations Board assessment in the teacher training programme,

- Update trainees on the new curriculum,

- Emphasise the teaching of practical lessons using available local materials

- Teach trainees how to teach large classes,

- Teach students how to manage the challenges of adolescents and youth as they develop

\section{Discussion}

\section{Subject content and delivery}

The findings show that on the whole teacher trainees from School of Education exhibit a masterly of the subject matter in the areas of specialization. Almost of the teachers who participated in the study reported that the trainees using appropriate teaching methods. These observations are confirmed by one of the administrators who pointed out that "some trainees are extremely excellent in the way they do their work as if they were regular teachers" These findings reveal that School of Education equip teacher trainees with adequate and appropriate content and with pedagogical skills to deliver the content to learners. However, there were a few reported cases in which some teacher trainees were short of the subject content while others employed teacher-centred methods to teach. This state of affairs can partly be explained by the fact that school practice by its nature, training and examination take place concurrently. The examination part brings a lot of anxiety to the trainees and as a result they fail to deliver their lessons as planned. This is why it was reported that "some trainees relate so closely with students for fear of being malice or let down during assessment" while others pointed out that "some trainees find it difficult to instill discipline in students as they fear to fail them during supervision". These statements clearly show that some trainees exhibit certain behaviors due to examination pressure. Although examination anxiety is a factor in way teacher trainees' conduct in the classroom, it does not rule out the fact that some trainees may actually lack the necessary subject content and or the appropriate pedagogical skills to deliver the required content. In such cases trainees with difficulties need to be identifies and given the necessary assistance. Teacher educators need to pay attention to pedagogical skills of the trainees and expose them to a variety of teaching methods.

On lighter note, some teachers reported that a number of the trainees experience difficulties in gauging enough content to be presented in a lesson, they end up teaching little content and covering few topics of the syllabus. This problem can only be over by encouraging teacher trainees to do a lot teaching but experience has shown that they are allocated a few lessons in a week. 


\section{Professional conduct of teacher trainees}

The findings also show that generally teacher trainees conduct themselves professionally during school practice. They are disciplined, dress decently, and relate with students in a professional way. This means that the trainees practice what they study in courses like professional ethics. The findings also revealed that a few trainees dress indecently while some male trainees fall in love with their female students. These isolated cases of indiscipline need to identified and reported to school of Education management so that they are handles according. Since university supervisors spend limited time in schools, it is not possible for them to identify such misconduct. Those cases of indiscipline do not reflect well on the institution where these teacher trainees come from, yet one of the values of internship, as argued by Niemi and Jakku-Sihvonen [2] is to strengthen and increase University's academic programme and reputation.

\section{Mentorship of Teacher Trainees}

The findings show that there is a loose partnership between the School of Education and the Secondary schools where the teacher trainees routinely go for school practice. It is loose in terms what the practicing teachers are expected to do when they receive the teacher trainees. Some practicing teachers receive them warmly and guide them, mentor, give them teaching materials, sit in their classes, others do not care or do not know what do and this is confirmed by Kagoda and Katabaro[6], Kagoda [7]. Some schools, especially private schools see internship as a period when they save money they would otherwise pay salary to teachers, therefore, they send them away and instead use teacher trainees. This is in line with Carpenter and Blance [3] who argue that " Schools have opportunity to having a pool of talented graduate teachers eligible for employment schools will make informed decisions regarding staffing needs" In other cases practicing teachers use this time to do some income generating activities since their salaries are very low. However, Carpenter and Blance [3] see this period as time for practicing teachers to do school projects; Practicing teachers get time to initiate new projects that will be of benefit to the school community.

\section{Conclusions}

The findings have clearly shown that practicing teachers believe that generally teacher trainees from Makerere University, School of Education are adequately trained. They demonstrate masterly of the subject matter in their subject of specialization and they deliver the content to students using appropriate instructional methods. Majority of the trainees conduct themselves professionally while on school practice. Most of the practicing teachers in the schools where trainees conduct school practice from do not provide mentorship to the trainees; they leave them to work on their own. School practice period is considered by practicing teachers as time to rest or do other things. The findings also revealed that trainees need assistance in aspects like handling large classes and adolescents, use learner-centred teaching methods and exposure to the current teaching syllabus developed by the National Curriculum Development Centre.

\section{Implications for teacher education}

This study has number implications to teacher education. Firstly, Teacher training institutions need to develop clear guidelines on how schools should participate in the training of teachers. The guidelines are essential for the provision of mentorship to trainees by the practicing teachers. Secondly, school administrators should ensure that their teachers do not abandon classes to teacher trainees instead they should work with them so as to get the necessary guidance since university supervisors spend little time with the trainees while at school. Thirdly, the component of professional ethics in teacher training programmes should be strengthened by teacher educators so that trainees conduct themselves according to the requirements of the teaching profession. Lastly, teacher training institutions should work out a mechanism of obtaining feedback from schools about trainees' conduct which should form part of the trainees' appraisal process.

\section{REFERENCES}

[1] Vescio. V; Ross. D. and Adams. A. A review of Research on the Impact of Professional learning communities on Teaching Practice and student learning. Teaching and Teacher Education 24, 80-91, 2008.

[2] Niemi H. and Jakku - Silvvonea. Teacher Education Curriculum of secondary school Teachers. University of Helsinki, Department of Education: Helsinki Finland, 2010.

[3] Carpenter L. and Blance Bette. Teaching Internships and the Learning community in Townsend and Bates R. (Eds) Handbook of Teacher Education. Griffith University, School of Education, 2007. www.98.griffth.education.

[4] Board of Teacher Registration. In Carpentor L and Blance B. (2007) Teaching Internships and the Learning community in Townsend and Bates R. (Eds) Handbook of Teacher Education. Griffith University, School of Education, 2003. www.98.griffth.education.

[5] Faculty of Education, University of Regina. Internship, learning to teach: A share Responsibility Rigina. Saskatchewan Canada, 2013. http://education.u.regina.ca

[6] Kagoda A M. and Katabaro. Funding school practice, its effect on behaviour and practices of Teaching practice supervisors in two East African University. Africa Review of Education, 2013

[7] Kagoda A.MThe Influence of the Schools Learning Environment on the performance of Teacher Trainees on School Practice; A Case of The School of Education. Makerere University, Uganda. Current Research Journal of Social Sciences 3(3) 244-252, 2011 